\author{
Yurinets Yulia, \\ Doctor of Law, Associate Professor, \\ Professor of the Department of Constitutional and \\ administrative law \\ Law Institute of the National Aviation University \\ ORCID 0000-0003-0281-3251 \\ iurynetsjulia@ukr.net \\ Belkin Mark, \\ $\mathrm{PhD}$ in law, lawyer \\ ORCID 0000-0003-0805-9923 \\ advokat@etalon.co.ua \\ Belkin Leonid, \\ $\mathrm{PhD}$ in Technical Sciences, \\ Senior Research Associate, lawyer \\ ORCID 0000-0001-8672-8147 \\ belkinleonid@ukr.net
}

\title{
PROBLEMS OF TERMINOLOGICAL UNIFICATION IN THE FIELD OF PUBLIC GOVERNANCE BY TRANSBOUNDARY MOVEMENT OF CULTURAL VALUES
}

The purpose of the study is to identify terminological inconsistencies and gaps in administrative regulation in the area of transboundary traffic control of cultural values in order to improve public administration in this area while ensuring the rights of citizens. Research methodology. The paper uses methods of documentary analysis and synthesis, comparative analysis, objective truth, which made it possible to trace systematically and compare terminological peculiarities in the sphere of cultural property protection - in Ukraine, on the one hand, in international conventions - on the other hand, and to study judicial practice on the documents of judicial authorities. The method of objective truth is realized by cross-checking of the source data of the research from several sources, relying on judicial practice and digital (statistical) material. The use of these methods contributed to obtaining of our own theoretical and practical results. Scientific novelty consists in formulating and developing the actual topic that has not received a comprehensive scientific coverage before and is investigated for the first time. The efficiency of using the idea of the matrix approach is substantiated in order to provide a systematic comparison of terminological peculiarities of various international and national acts in the sphere of cultural property protection and to find out the best practices of state regulation. Conclusions. Public administration of the cross-border movement of cultural property is an integral part of the state policy in the field of culture and concerns the issues of ensuring the preservation and accessibility of cultural property. Instead, in the legal field, the protection of cultural property does not have the proper terminology. Conflict and incompleteness of the domestic legal regulation in the sphere of export-import of cultural values are established, for example, when comparing the Law of Ukraine "On Export, Import and Return of Cultural Property», on the one hand, and the Ukrainian Classification of Goods for Foreign Economic Activity (UCT FEA), which is guided by international conventions, on the other hand. The lack of the criteria for identifying cultural assets, which should be protected creates a situation of legal uncertainty in the transportation of certain types of values across borders that violate the rights of citizens.

Keywords: terminology, cultural values, cultural heritage, unification of terminology, transboundary movement of cultural property, collectibles and antiques.

Юринець Юлія Леонідівна, доктор юридичних наук, доцент, профресор кафредри конституційного та адміністративного права Юридичного інституту Національного авіаційного університету; Бєлкін Марк Леонідович, кандидат юридичних наук, адвокат; Бєлкін Леонід Михайлович, кандидат технічних наук, старший науковий співробітник, адвокат цінностей

Проблеми термінологічної уніфікації у сфері державного управління транскордонним рухом культурних

Мета дослідження полягає у виявленні термінологічних неузгодженостей та прогалин адміністративного регулювання у сфері контролю транскордонного руху культурних цінностей задля поліпшення державного управління у цій сфері при одночасному забезпеченні прав громадян. Методологія дослідження. У роботі використано методи документального аналізу і синтезу, порівняльного аналізу, об'єктивної істини, що дало змогу системно простежити та порівняти термінологічні особливості у сфері охорони культурного надбання - в Україні, з одного боку, у міжнародних конвенціях - з іншого боку, за документами судової влади вивчити судову практику. Метод об'єктивної істини реалізується шляхом перехресної перевірки вихідних даних дослідження із декількох джерел, опори на судову практику та цифровий (статистичний) матеріал. Використання вказаних методів сприяло отриманню власних теоретичних і практичних результатів. Наукова новизна полягає у постановці й розробці актуальної теми, яка раніше не одержала всебічного наукового висвітлення та досліджується вперше. Обґрунтовано ефективність використання ідеї матричного підходу задля наочного системного порівняння термінологічних особливостей різних міжнародних та національних актів у сфері охорони культурного надбання та з'ясування кращих практик державного регулювання. Висновки. Державне управління транскордонним рухом культурних цінностей є складовою частиною державної політики в галузі культури і стосується проблематики забезпечення збереження культурних цінностей та доступу до них. Натомість у правовому полі охорона культурних цінностей не має належного термінологічного забезпечення. Встановлена суперечливість та неповнота вітчизняного правового регулювання у сфері вивезення-ввезення культурних цінностей, наприклад, при порівнянні Закону України «Про вивезення, ввезення та повернення культурних цінностей», з одного боку, та Українського класифрікатора товарів зовнішньоекономічної діяльності (УКТ ЗЕД), який орієнтується на міжнародні конвенції, з іншого боку. Відсутність критеріїв для визначення культурних цінностей, які мають користуватися охороною, створює ситуацію правової невизначеності при перевезенні певних видів цінностей через кордон, що порушує права громадян.

Ключові слова: термінологія, культурні цінності, культурна спадщина, уніфікація термінології, транскордонний рух культурних цінностей, предмети колекціонування та антикваріат.

(c) Yurinets Y., 2019

(C) Belkin M., 2019

(C) Belkin L., 2019 
Юринец Юлия Леонидовна, доктор юридических наук, доцент, профрессор кафедры конституционного и административного права Юридического института Национального авиационного университета; Белкин Марк Леонидович, кандидат юридических наук, адвокат; Белкин Леонид Михайлович, кандидат технических наук, старший научный сотрудник, адвокат

Проблемы терминологической унификации в сфере государственного управления трансграничным движением культурных ценностей

Цель исследования заключается в выявлении терминологических несогласованностей и пробелов административного регулирования в сфере контроля трансграничного движения культурных ценностей для улучшения государственного управления в этой сфере при одновременном обеспечении прав граждан. Методология исследования. В работе использованы методы документального анализа и синтеза, сравнительного анализа, объективной истины, что позволило системно проследить и сравнить терминологические особенности в сфере охраны культурного наследия - в Украине, с одной стороны, в международных конвенциях - с другой стороны, по документам судебной власти изучить судебную практику. Метод объективной истины реализуется путем перекрестной проверки исходных данных исследования с нескольких источников, опоры на судебную практику и цифровой (статистический) материал. Использование указанных методов способствовало получению собственных теоретических и практических результатов. Научная новизна заключается в постановке и разработке актуальной темы, которая ранее не получила всестороннего научного освещения и исследуется впервые. Обоснована эффрективность использования идеи матричного подхода для наглядного системного сравнения терминологических особенностей различных международных и национальных актов в сфере охраны культурного наследия и выяснения лучших практик государственного регулирования. Выводы. Государственное управление трансграничным движением культурных ценностей является составной частью государственной политики в области культуры и касается проблематики обеспечения сохранности культурных ценностей и доступа к ним. Однако в правовом поле охрана культурных ценностей не имеет надлежащего терминологического обеспечения. Установлена противоречивость и неполнота отечественного правового регулирования в сфере вывоза-ввоза культурных ценностей, например, при сравнении Закона Украины «О вывозе, ввозе и возвращении культурных ценностей», с одной стороны, и Украинского классификатора товаров внешнеэкономической деятельности (УКТ ВЭД), который ориентируется на международные конвенции, с другой стороны. Отсутствие критериев для определения культурных ценностей, которые должны пользоваться охраной, создает ситуацию правовой неопределенности при перевозке определенных видов ценностей через границу, что нарушает права граждан.

Ключевые слова: терминология, культурные ценности, культурное наследие, унификация терминологии, трансграничное движение культурных ценностей, предметы коллекционирования и антиквариат.

Problem statement. Since 1970 - the time of the adoption of the Convention on the Means of Prohibiting and Preventing the Illicit Import, Export and Transfer of Ownership of Cultural Property 1970 [1] - the international community officially considers unacceptable the uncontrolled movement of cultural property across the border. The preamble to the Convention [1] states that cultural property constitutes one of the basic elements of civilization and national culture, and that its true value can be appreciated only in relation to the fullest possible information regarding its origin, history and traditional setting.

A number of works [2-5, etc.] are devoted to the study of various aspects of state regulation of the crossborder movement of cultural property. One such aspect is the uncertainty of terminology in the field of the protection of objects of cultural property [5]. Such uncertainty does not allow the exact «agreement» that we protect. As stated in the article [6, p. 119-120], one of the most important factors that negatively affects the national legislative defense process is the lack of well-defined terminology, as well as the corresponding conceptual complex. The article [5, p. 12, 14] also notes that the activities of the authorities in the sector of import-export operations with cultural values in terms of classification of objects is not coordinated. Consequently, the study of questions of unification of terminology in the sphere of cultural values protection, in particular in the field of cross-border movement of cultural values, is relevant.

Analysis of research and publications. Issues of the problem of terminological unification in the field of the protection of cultural property, as well as problems arising as a result of not solving the first problems, are studied in certain scientific publications. Yes, I.V. Pivovar emphasizes that the existence of legal science in the legal category «cultural values» has a conceptual significance within the framework of the problem of their legal protection. However, the lack of jurisprudence (doctrine and practice) of a single understanding of this concept complicates the operation of this category in law enforcement activities and does not contribute to the development of optimal solutions to the mechanisms of its legal regulation [7].

V. Karpov [5, p. 14] notes that in the segment of control over the movement of cultural property through the customs border, the normative base of state departmental institutions that carry out this process is not coordinated, functions separately and does not form a system [5, p. 14].

Some issues of the terminological classification of cultural property were considered by one of the authors of this paper in articles $[8,9]$.

The purpose of the study is to identify terminological inconsistencies and gaps in administrative regulation in the area of transboundary traffic control of cultural values in order to improve public administration in this area while ensuring the rights of citizens.

Statement of basic materials. Approaches to international and domestic legal regulation of cultural property are heterogeneous. However, the generalization of the leading international and European cultural protection conventions shows that in the vast majority of cases, immovable and Immaterial cultural values are defined as heritage, and "cultural values» in accordance with the accepted lists are considered only as movable (except those that are combined with the real object of cultural heritage). This direct definition of «movable cultural property» is used in the Recommendation [10]. Such an emphasis on «mobility» is explained by practical considerations, namely that the features of protection of such values are associated primarily with the prevention of their displacement, including those associated with the theft. Only in The Hague Convention 
on the Protection of Cultural Property in the event of Armed Conflict [11] the concept of «cultural values» includes immovable values.

The summary of risks for movable cultural heritage objects is contained in the preamble of the Convention [1]: theft, clandestine excavation, illegal export. This and encouraging thefts in most cases are due to the intention of illegal export, as noted in the 2002 French insurance group «Argos», "countries such as Russia, Ukraine, Belarus, Poland, the former Czechoslovakia are systematically emptied, robbed by organized gangs, who steal cultural property in the East to sell them in the West» [12, p. 249]. Hence, countering the illegal movement of cultural property is an urgent task for the countries.

According to tradition descriptive approach to the definition of «cultural property», the range of values that are subject to control when moving across borders, is found particularly in the Convention [1], Convention [13], Recommendation [10] and the Law of Ukraine [14] (Art. 1). Comparative list of values for the listed acts listed in Table 1.

The comparison shows that the definition of «cultural values» are considered as acts in the direction of regulation about the same. This and definition laid down in the Law [14], approximate convention. However, as you know, "the devil is in the details». And «in the details» differences can be so significant that the opposite way can change the membership or qualification of not belonging of the object to the class of «cultural values».

The comparison provided in table 1 shows that even at the level of international acts, even of the authorship of one publisher (UNESCO [1] and [10]) terminology cannot be fully standardized, although in this case it cannot be justified by the different objectives of regulation, as the objectives are identical - to streamline and limit the movement of cultural values across borders. Also it draws attention that the Convention [13] identified two general categories of cultural values: those for which the recognition of crimes is mandatory and those for which the recognition of crimes is recognized optional (see the note to table 1).

With regard to regulation under the Law [14], the list envisaged in it is unsatisfactorily adapted for practical activity. For example, the Ukrainian lawmaker was unable to use the list of cultural values in accordance with the law [14], even for the compilation of the relevant section of the UCT FEA (Table 2). According to Part 5 of Art. 374 of the Customs Code of Ukraine, cultural values according to the codes 970110 00 00, 97019000 00, 97020000 00, 97030000 00, 97040000 00, 97050000 00, 9706000000 according to the UKT FEA, which are manufactured 50 or more years ago, regardless of cost and method of movement across the customs border of Ukraine are subject to a written declaration.

Table 2 shows an excerpt of this classifier on the goods of group 97.

The comparisons provided in table 2 show that the source of the recognition of certain groups of goods as such that are cultural values and subject to be declared, in its substantial part is not based directly on the definition from the law [14], but is based directly on the Convention [1]. Although the Convention ratified by Ukraine is also part of the Ukrainian legislation, there are no reasonable grounds not to align the law [14] with the Convention [1] to avoid artificial conflicts, especially as the practice of creating the UCG FEA showed greater acceptability of the Convention [1]. These differences pose significant problems in real customs clearance of goods that can be considered cultural values.

According to the law [14] under any circumstances the following cannot be taken abroad: cultural values listed in the State Register of Cultural Heritage; the cultural values included in the National Archive Fund; the cultural values included in the Museum Fund of Ukraine (art. 14 of the law [14]).

It also draws attention that in the law [14], in contrast to the Convention [1], there is no mention of such objects of movable cultural values, as parts of dismantled archaeological sites. The latter is particularly important in the context of unauthorized excavations of archaeological monuments, which recently reached alarming levels in Ukraine. It also makes evident the inconsistency of Ukrainian legal regulation because in the law [14] these objects are considered objects of movable cultural heritage. In return, in the Convention [1], in the context of export restrictions, the state's responsibility is to organize the monitoring of archaeological excavations, conserve «in situ» (in place) certain cultural values and protect some areas remaining for future archaeological excavations (article 5, p. «d»).

It should also be noted that Ukraine has established a list of gift items, objects of cultural and utilitarian purpose of serial and mass production that are not related to the cultural values and for the exportation (temporary exportation) of which permission is not required. This list includes:

a) cultural values temporarily imported into Ukraine, in the presence of customs declaration, issued in the established order during import (transfer) in Ukraine of these values;

b) works of contemporary art, folk crafts, souvenirs purchased in trading network;

c) painting, plastic of small forms, original drawings, tapestries, items of decorative art of ceramics, porcelain, pottery, glass, wood, metal, textiles and other materials, established since 1950;

d) domestic and foreign everyday objects of mass production and mass created after 1950 (on the list);

d) modern religious artifacts of different confessions, icons, made by printing, as well as crosses, lamps, candlesticks and other religious printed production;

e) items of technology: cars, motorcycles, bicycles and other vehicles that do not have significant historical value (under considerable historical value means: belonging to celebrities, politicians, participation in outstanding events, exclusive models that have not been in mass production or produced in small quantities, or anniversary, or issued before 1950 and their number in Ukraine not more than two copies); watches (clocks, floor, wall, etc.) 
made after 1950; modern model aircraft, cars, ships and other items of equipment; phonographs and records (starting number 285 for records "MONO" and the number 739 for records "STEREO") manufactured after 1960;

g) printing works published after 1945 (on the list);

h) musical instruments in the presence of one of the documents: passport factory, a trading receipt, check the label on the instrument, etc., made after 1950, incl.: factory serial domestic and foreign production; mechanical tools and instruments of factory production;

i) postage stamps of Ukraine, stamps and blocks, labeled envelopes and marked postcards (artistic and standard), issued after 1991;

k) personal rewards, in case of movement of citizens for permanent residence to other states, in the presence of medal books or award certificates. Exportation by citizens, who move to permanent residence in another state, of awards left by the deceased parent may be subject to submission of documents confirming the relocation of citizens for permanent residence in another state, the death certificate, medal books or award certificates and documents proving kinship;

l) state awards of Ukraine of precious metals and / or precious stones, the export of which was approved by the Cabinet of Ministers of Ukraine of 21.06.2001. number 677;

m) badges, commemorative plates, table medals, jubilee and commemorative coins, banknotes that are not a means of payment (except domestic and foreign coins made of precious and non-precious metals, paper money until 1960 inclusively).

It is also allowed to freely repatriate copies of documents of the National Archive Fund and extracts from these documents, in addition to copies of the documents containing information classified as state and other secrets, provided by law, and excerpts from those documents.

It should be noted that in these cases, normative regulation is exercised by the way of defining the criteria under which the rules of export of cultural values do not apply (negative criteria). However, according to the p. 2, art. 1 section I of the Recommendation [10], each State-member must establish the most appropriate, in its view, criteria for determining the values that are in its territory, that have to be covered by the protection provided for in this Recommendation because of their archaeological, artistic, scientific or technical values, i.e. positive criteria. However, currently these criteria in Ukraine have not been set [15]. This often creates a situation of legal uncertainty during the carriage of certain types of property across the border, as evidenced by the jurisprudence.

Thus, in the Resolution of the Kyiv District Court of the city of Kharkiv of 21.04.2016, case number $640 / 6170 / 16-p$, as the subject of violation of customs rules there were considered 26 icons, which, according to experts, have historic and ethnographic value, their total cost is 4.000 USD. At that, it is not specified in any document which rule of which law has been broken. Thus, among the restrictions listed in the table 2 , such a thing as «icons» is not mentioned at all; the terms «ethnographic significance», "ethnographic value» either (except the context of weapons), to which, by the way, the author had drawn attention in the author's article [15].

In the Decree of Kovpakivskiy District Court of the city of Sumy of 12.04.2016, case number $592 / 3597 / 16-p$, as the subject of violation of customs regulations there is considered «samovar metallic yellow (1899), without a cap, without closure, which overrides the supply of water». This object does not fall under any definition from the table 1. The Court stated that the customs authorities had not indicated any breach of the rules of Instruction number 258 committed by the person.

In return, in the Resolution of the Court of Appeal of Zaporozhye region of 18.03.2016, case number $334 / 9731 / 15-p$, as the subject of violation of customs regulations there is considered «samovar metallic yellow, flame (without electric power), estimated to have been produced in 1908 (producer: Tula samovar factory «Баташевъ», master «Василій Сергіъевичъ Котыревъ», all hallmarks made in font and language different from the modern Russian language)». As a result, the person was convicted, although this samovar is not covered by restrictions of the law, but the court still considered it a violation because permission is not needed only for the export of domestic and foreign consumer goods of mass and serial production created only after 1950.

V. Karpov reports that the Kyiv Regional Research and Forensic Science Center of the Ministry of Internal Affairs of Ukraine issued a conclusion to the Belotserkiv Museum of Local Lore regarding the evaluation of historical cold and firearms as "souvenir and that which is a kind of household and household purpose." [4, p. 5].

Thus, despite more than 15-year history of validity of the law [14], in fact this law has not established complete regulation of issues of export-import of cultural values.

Certain inconsistencies regarding the recognition of "cultural values" precisely as movable values are contained in the Civil Code of Ukraine (hereinafter - CCU). Thus, in part 8 of Art. 319 CCU provides that «the peculiarities of realization of the right of ownership to cultural values shall be established by law». That is, given the tradition of considering «moving objects» as «cultural values», there may be the impression that the peculiarities of realization of the right of ownership may extend only to such objects. However, in Part 5 of Art. 346 and in art. 352 CCU provides for the possibility of compulsory redemption of monuments of cultural heritage, and this is also a feature that has remained unnoticed in the special article 319 CCU, which sets the peculiarities.

In addition, in Part 3 of Art. 727 CCU stipulates that «the donor has the right to demand the termination of a donation contract if, as a result of the neglected attitude of the gifted to a thing which is of cultural value, 
this thing can be destroyed or substantially damaged». In this formulation, there remains uncertainty: whether this is the right of the donor to only movable objects, or extends to immovable. For example, when considering a dispute about the cancellation of a donation contract for an apartment (immovable property), the Court of Appeal of Zaporizhzhya Oblast in its ruling dated 06.12.2012 in the case number 22/94788/12 denied the status of an apartment as a cultural property with reference to the definition of cultural value given in Art. 1 law [14], since from the context of this definition (the list below) there follows the understanding of "cultural values» as moving things.

Conclusions. Public administration of the cross-border movement of cultural property is an integral part of state policy in the field of culture and concerns the issues of ensuring the preservation and accessibility of cultural property. Instead, in the legal field, the protection of cultural property does not have the proper terminology. Conflict and incompleteness of the domestic legal regulation in the sphere of export-import of cultural values are established. The lack of criteria for identifying cultural assets that should be protected creates a situation of legal uncertainty in the transport of certain types of values across borders that violate the rights of citizens. The above shows that although unification of definitions of "cultural values" is not always feasible, but it is necessary, at least in those areas, where the absence of such unification prevents practical work on protection of culture.

\section{תimepamypa}

1. Конвенція про заходи, спрямовані на заборону та запобігання незаконному ввезенню, вивезенню та передачі права власності на культурні цінності (Париж, 14.11.1970).

2. Платонов Б.О. Огляд ринків і прогнозування оціночної вартості художніх творів (частина 1 - світові ринки) // Вісник Національної академії керівних кадрів культури і мистецтв. 2017. № 4. С. 106-113.

3. Індутний В.В. Ринки культурних цінностей: порівняльний аналіз // Вісник Національної академії керівних кадрів культури і мистецтв. 2014. № 1. С. 19-27.

4. Карпов В.В. Державна політика у сфері надання послуг з експертизи культурних цінностей // Вісник Національної академії керівних кадрів культури і мистецтв. 2017. № 2. С. 3-7.

5. Карпов В.В. Імпортно-експортні операції на ринку культурних цінностей // Вісник Національної академії керівних кадрів культури і мистецтв. 2017. № 3. С. 12-16.

6. Парацій В.М. Понятійний комплекс національного пам'ятко-охоронного законодавства: фрактори терміно-етимологічної невідповідності // Міжнародний досвід охорони культурної спадщини та пам'ятко-охоронне законодавство України: Матеріали конференції (18-19 квітня 2002 р.). К. : Стилос. 2002. С. 119-124.

7. Пивовар І.В. Окремі аспекти дослідження поняття «культурні цінності» // Право і суспільство. 2008. № 6. С. 144-149.

8. lurynets J.L. International approaches to classification of the objects of the world cultural and natural heritage protection. Juridical Sciences and Education. - 2015. № 45. Baku. p. 103-120.

9. Yurinets J., Pyvovar I., Pyvovar Yu. Problems of Legal Unification of the Concept of "Cultural Values» in Ukrainian and International Legislation. Advanced Science Letters. Volume 24, Number 4, April 2018, pp. 2936-2939 (4).

10. Рекомендація про охорону рухомих культурних цінностей : ЮНЕСКО, Париж, 28.11.1978 г.

11. Гаазька Конвенція про захист культурних цінностей на випадок збройного конфлікту, від 14.05.1954 p.

12. Боряк Г. Крадіжки в архівах і національна архівна спадщина: сучасні загрози та світовий досвід запобігання втратам // Архіви України. 2006. № 1-6. С. 247-288.

13. European Convention on Offences relating to Cultural Property (ETS No.119) (Delphi, 23.06.1985).

14. Про вивезення, ввезення та повернення культурних цінностей : Закон України // ВВР. 1999. № 48. Ст. 405.

15. Юринець Ю. Митний контроль за вивезенням культурних цінностей в контексті міжнародних зобов'язань України // Митна справа. 2011. № 1. С. 25-34.

\section{References}

1. Convention on the Means of Prohibiting and Preventing the Illicit Import, Export and Transfer of Ownership of Cultural Property (Paris, 14.11.1970) [in Ukrainian].

2. Platonov B., Mazur V. (2017). Review of markets and forecasting of the estimated value of works of art (Part I - world markets). Visnik Natsionalnoyi Akademiyi kerivnih kadriv kulturi i mistetstv, 4, 106-113 [in Ukrainian].

3. Indutnyy V. (2014). Cultural property markets: a comparative analysis. - Visnik Natsionalnoyi Akademiyi kerivnih kadriv kulturi i mistetstv, 1, 19-27 [in Ukrainian].

4. Karpov V. (2017). Government policy in providing services for the examination of cultural values. - Visnik Natsionalnoyi Akademiyi kerivnih kadriv kulturi i mistetstv, 2, 3-7 [in Ukrainian].

5. Karpov V. (2017). Import-export operations in the market of cultural valuables. Visnik Natsionalnoyi Akademiyi kerivnih kadriv kulturi i mistetstv, 3, 12-16 [in Ukrainian].

6. Paratsiy V.M. (2002). Conceptual complex of national monument protection legislation: factors of terminological-etymological mismatch. Mizhnarodniy dosvid ohoroni kulturnoyi spadschini ta pam'yatko-ohoronne zakonodavstvo ukrayini : materiali konferentsiyi (18-19 kvitnya 2002 r.) K. : Stilos, 119-124 [in Ukrainian].

7. Pivovar I.V. (2008). Separate aspects of the study of the concept of «cultural values». Pravo i suspilstvo, 6, 144-149.

8. lurynets J.L. (2015). International approaches to classification of the objects of the world cultural and natural heritage protection. Juridical Sciences and Education, 45. Baku, 103-120.

9. Yurinets J., Pyvovar I., Pyvovar Yu. (2018). Problems of Legal Unification of the Concept of «Cultural Values» in Ukrainian and International Legislation. Advanced Science Letters, 24, 4, April 2018, 2936-2939 (4) [in Ukrainian].

10. Recommendation on the protection of movable cultural property: UNESCO, Paris, 28.11.1978 [in Ukrainian].

11. Hague Convention on the Protection of Cultural Property in the event of armed conflict on 14.05.1954 [in Ukrainian].

12. Boryak, G. (2006). Theft in the archives and national archival heritage: modern threats and global experience of loss prevention.

Arhivi Ukrayini, 1-6, 247-288 [in Ukrainian].

13. European Convention on Offences relating to Cultural Property (ETS No.119) (Delphi, 23.06.1985) [in English].

14. On export, import and return of cultural property: The Law of Ukraine // BD. 1999, 48, Art. 405 [in Ukrainian].

15. Yurinets Yu. (2011). Customs control over the export of cultural property in the context of international obligations of Ukraine. Mitna sprava, 1, 25-34 [in Ukrainian]. 


\section{Comparison of objects of cultural values}

\begin{tabular}{|c|c|c|c|}
\hline $\begin{array}{l}\text { Definition in accordance } \\
\text { with the Convention [1] }\end{array}$ & $\begin{array}{c}\text { Definition in accordance } \\
\text { with the Recommendation } \\
\text { [10] }\end{array}$ & $\begin{array}{l}\text { Definition in accordance with the } \\
\text { Convention [13] }\end{array}$ & $\begin{array}{l}\text { Definition in accordance with } \\
\text { the law [14] }\end{array}$ \\
\hline 1 & 2 & 3 & 4 \\
\hline $\begin{array}{l}\text { a) rare collections and } \\
\text { specimens of flora and } \\
\text { fauna, mineralogy, } \\
\text { anatomy and items of } \\
\text { interest to paleontology; }\end{array}$ & $\begin{array}{l}\text { xi) zoological, botanical } \\
\text { and geological specimens; }\end{array}$ & $\begin{array}{l}\text { h) rare collections and specimens of } \\
\text { fauna; } \\
\text { i) rare collections and specimens of } \\
\text { flora; } \\
\text { j) rare collections and specimens of } \\
\text { minerals; } \\
\text { k) rare anatomical collections and } \\
\text { samples; } \\
\text { l) objects of interest in terms of } \\
\text { paleontology; }\end{array}$ & $\begin{array}{l}\text { zoological } \begin{array}{r}\text { collections } \\
\text { representing scientific, }\end{array} \\
\text { cultural, teaching and } \\
\text { educational or aesthetic } \\
\text { value; rare collections and } \\
\text { specimens of flora and } \\
\text { fauna, mineralogy, anatomy } \\
\text { and paleontology; }\end{array}$ \\
\hline $\begin{array}{l}\text { b) values relating to } \\
\text { history, including the } \\
\text { history of science and } \\
\text { technology, history of wars } \\
\text { and societies, as well as } \\
\text { those related to the life of } \\
\text { national leaders, thinkers, } \\
\text { scientists and artists and } \\
\text { with major national events; }\end{array}$ & $\begin{array}{l}\text { v) historical values, incl. } \\
\text { those related to the history } \\
\text { of science and technology, } \\
\text { military and social history, } \\
\text { as well as the life of } \\
\text { peoples and national } \\
\text { leaders, thinkers, } \\
\text { scientists and artists and } \\
\text { events of national } \\
\text { importance; }\end{array}$ & $\begin{array}{l}\text { e) items related to history, including } \\
\text { the history of science and technology, } \\
\text { military history and the history of } \\
\text { society; } \\
\text { f) items related to the life of national } \\
\text { leaders, thinkers, scientists and artists; } \\
\text { g) items related to important national } \\
\text { events; }\end{array}$ & $\begin{array}{l}\text { items related to historical } \\
\text { events, development of state } \\
\text { and society, history, science } \\
\text { and culture, as well as those } \\
\text { relating to the life and work } \\
\text { of prominent statesmen, } \\
\text { political parties, public and } \\
\text { religious organizations, } \\
\text { science, culture and art; }\end{array}$ \\
\hline $\begin{array}{l}\text { c) archaeological findings } \\
\text { (including regular and } \\
\text { clandestine) and } \\
\text { archaeological } \\
\text { discoveries; }\end{array}$ & $\begin{array}{l}\text { i) findings as a result of } \\
\text { terrestrial and underwater } \\
\text { archaeological research } \\
\text { and excavations; }\end{array}$ & $\begin{array}{l}\text { a) archaeological findings resulting } \\
\text { from archaeological research and } \\
\text { excavations (including regular and } \\
\text { illegal ones) conducted on land and } \\
\text { under water; } \\
\text { q) all remains and objects, or other } \\
\text { traces of human existence, which are } \\
\text { evidence of epochs and civilizations } \\
\text { for which excavations and discoveries } \\
\text { are the main or a major source of } \\
\text { scientific information; }\end{array}$ & $\begin{array}{l}\text { objects of museum value, } \\
\text { found during archaeological } \\
\text { excavations; }\end{array}$ \\
\hline $\begin{array}{l}\text { d) components of } \\
\text { dismantled artistic and } \\
\text { historical monuments and } \\
\text { archaeological sites; }\end{array}$ & $\begin{array}{l}\text { iii) items of historical } \\
\text { monuments that suffered } \\
\text { fragmentation; }\end{array}$ & $\begin{array}{l}\text { b) elements of artistic and historical } \\
\text { monuments or archaeological sites } \\
\text { which have undergone fragmentation; }\end{array}$ & $\begin{array}{l}\text { parts and fragments of } \\
\text { architectural, historical and } \\
\text { artistic monuments and } \\
\text { monumental art; }\end{array}$ \\
\hline \multirow[t]{2}{*}{$\begin{array}{l}\text { e) antiquities more than } \\
100 \text { years old, such as } \\
\text { inscriptions, minted coins } \\
\text { and stamps; }\end{array}$} & $\begin{array}{l}\text { ii) antiquities such as } \\
\text { tools, pottery, inscriptions, } \\
\text { coins, seals, jewelry, } \\
\text { weapons and items from } \\
\text { the graves, including } \\
\text { mummies; }\end{array}$ & $\begin{array}{l}\text { f) tools, pottery, inscriptions, coins, } \\
\text { seals, jewelry, weapons and burial } \\
\text { remains, including mummies, more } \\
\text { than a hundred years old; }\end{array}$ & \\
\hline & & $\begin{array}{l}\text { a) original art collections and } \\
\text { assembling of any material that are } \\
\text { essential for the artistic, historical, } \\
\text { archaeological, scientific and other } \\
\text { fields of culture; }\end{array}$ & \\
\hline f) ethnological materials; & $\begin{array}{l}\text { iv) anthropological and } \\
\text { ethnological materials; }\end{array}$ & $\begin{array}{l}\text { m) materials that are of interest in } \\
\text { terms of Anthropology; } \\
\text { n) objects of interest in terms of } \\
\text { Ethnology; }\end{array}$ & \\
\hline $\begin{array}{l}\text { g) artistic values, such as: } \\
\text { i) paintings, drawings } \\
\text { entirely hand-made on any } \\
\text { base and of any materials } \\
\text { (excluding drawings and } \\
\text { industrial products, which } \\
\text { are decorated by hand); } \\
\text { ii) original works of } \\
\text { sculptural art of any } \\
\text { material; } \\
\text { iii) original engravings, } \\
\text { prints and lithographs; } \\
\text { iv) original artistic } \\
\text { selections and installations } \\
\text { of any materials; }\end{array}$ & $\begin{array}{l}\text { vi) artistic values, such as: } \\
\text { - paintings and drawings } \\
\text { completely handmade on } \\
\text { any basis and of any } \\
\text { materials (except drawings } \\
\text { and industrial products, } \\
\text { decorated by hand); } \\
\text { - original prints, posters } \\
\text { and photographs, as a } \\
\text { kind of original creation; } \\
\text { - original artistic selections } \\
\text { and installations of any } \\
\text { material; } \\
\text { - sculptural works of any } \\
\text { materials; } \\
\text { - works of crafts of } \\
\text { materials such as glass, } \\
\text { ceramic, metal, wood etc. }\end{array}$ & $\begin{array}{l}\text { c) pictures, paintings and drawings, } \\
\text { hand-made on any basis and using any } \\
\text { materials, that are essential to the } \\
\text { artistic, historical, archaeological, } \\
\text { scientific and other areas of culture; } \\
\text { d) original works of sculpture from any } \\
\text { material that are essential for the artistic, } \\
\text { historical, archaeological, scientific and } \\
\text { other areas of culture, as well as parts of } \\
\text { such works; } \\
\text { e) original engravings, prints, lithographs } \\
\text { and photographs which are important for } \\
\text { the artistic, historical, archaeological, } \\
\text { scientific and other fields of culture; } \\
\text { b) works of applied art from materials } \\
\text { such as glass, ceramics, metal, wood, } \\
\text { etc., that are essential to the artistic, } \\
\text { historical, archaeological, scientific and } \\
\text { other fields of culture; }\end{array}$ & $\begin{array}{l}\text { original art paintings, } \\
\text { drawings and sculptures, } \\
\text { artistic compositions and } \\
\text { assembling of any material, } \\
\text { works of decorative and } \\
\text { traditional folk art; }\end{array}$ \\
\hline
\end{tabular}




\begin{tabular}{|c|c|c|c|}
\hline 1 & 2 & 3 & 4 \\
\hline $\begin{array}{l}\text { h) rare manuscripts and } \\
\text { incunabula, old books, } \\
\text { documents and publications } \\
\text { that are of special interest } \\
\text { (historical, artistic, scientific, } \\
\text { literary, etc.), singly or in } \\
\text { collections; }\end{array}$ & $\begin{array}{l}\text { vii) manuscripts and } \\
\text { incunabula, codes, books, } \\
\text { documents or publications of } \\
\text { special interest; }\end{array}$ & $\begin{array}{l}\text { i) rare manuscripts and incunabula, single } \\
\text { or in collections; } \\
\text { c) old books, documents and publications } \\
\text { of special interest (historical, artistic, } \\
\text { scientific, etc.), individually or in } \\
\text { collections; }\end{array}$ & $\begin{array}{l}\text { old books and other } \\
\text { publications that are of } \\
\text { historical, artistic, scientific and } \\
\text { literary value, individually or in } \\
\text { collections; manuscripts and } \\
\text { incunabula, old books ... } \\
\text { individually or in collections; }\end{array}$ \\
\hline $\begin{array}{l}\text { i) postage stamps, tax and } \\
\text { similar stamps, singly or in } \\
\text { collections }\end{array}$ & & $\begin{array}{l}\text { o) objects of interest in terms of philately; } \\
\text { p) rarities of interest in terms of } \\
\text { numismatic (medals and coins); }\end{array}$ & $\begin{array}{l}\text { rare stamps, other philatelic } \\
\text { materials, singly or in } \\
\text { collections; }\end{array}$ \\
\hline $\begin{array}{l}\text { j) Archives, including phono-, } \\
\text { photo and film archives; }\end{array}$ & $\begin{array}{l}\text { viii) objects of interest in } \\
\text { terms of numismatic (medals } \\
\text { and coins) or philately; }\end{array}$ & $\begin{array}{l}\text { d) archives, including records of texts, } \\
\text { maps and other cartographic materials, } \\
\text { photographs, films, sound recordings and } \\
\text { machine-readable records, that are } \\
\text { essential to artistic, historical, } \\
\text { archaeological, scientific and other fields } \\
\text { of culture; }\end{array}$ & $\begin{array}{l}\text { archive documents, including } \\
\text { film, photography and phono } \\
\text { documents, singly or in } \\
\text { collections; }\end{array}$ \\
\hline \multirow[t]{3}{*}{$\begin{array}{l}\text { k) furniture more than } 100 \\
\text { years old and old musical } \\
\text { instruments }\end{array}$} & $\begin{array}{l}\text { ix) archival documents, incl. } \\
\text { texts, maps and other } \\
\text { cartographic materials, } \\
\text { photographs, films, sound } \\
\text { recordings and documents } \\
\text { read by machines; }\end{array}$ & $\begin{array}{l}\text { g) pieces of furniture, tapestries, carpets } \\
\text { and clothes more than a hundred years } \\
\text { old; } \\
\text { h) musical instruments more than a } \\
\text { hundred years old; }\end{array}$ & $\begin{array}{l}\text { unique and rare musical } \\
\text { instruments; }\end{array}$ \\
\hline & $\begin{array}{l}\text { x) furniture, tapestries, } \\
\text { carpets, costumes and } \\
\text { musical instruments; }\end{array}$ & & $\begin{array}{l}\text { various types of weapons that } \\
\text { have artistic, historical, } \\
\text { ethnographic and scientific } \\
\text { value; }\end{array}$ \\
\hline & & & $\begin{array}{l}\text { family values - cultural values } \\
\text { having the nature of personal } \\
\text { or family objects }\end{array}$ \\
\hline
\end{tabular}

Note. States that have acceded to the Convention [13], must recognize its extension as to offenses committed against the cultural values listed in column 3 in plain type. Any Contracting State may at any time declare that it considers the offenses relating to cultural values also those listed in column 3 in italics.

\section{DIRECTORY}

of codes of goods in accordance with

the Ukrainian Classification of Goods for Foreign Economic Activities (UCG FEA)

Chapter XXI, Group 97

Works of art, collectibles and antiques

Table 2

\begin{tabular}{|c|c|c|}
\hline Code & Name according to UCG FEA & Analog \\
\hline 9701 & $\begin{array}{l}\text { Paintings, drawings and pastels, executed entirely by } \\
\text { hand, other than drawings of heading } 4906 \text { and other } \\
\text { finished products, painted or decorated by hand; } \\
\text { collages and similar decorative images: }\end{array}$ & \multirow[t]{3}{*}{$\begin{array}{l}\text { Original art paintings, drawings and sculptures, artistic } \\
\text { compositions and assembling of any material, works of } \\
\text { decorative and traditional folk art [14] }\end{array}$} \\
\hline 9701100000 & - Paintings, drawings and pastels & \\
\hline 9701900000 & - Others & \\
\hline 9702000000 & Original engravings, prints and lithographs & $\begin{array}{l}\text { Original engravings, prints and lithographs. [1] Absent } \\
\text { in the law [14] }\end{array}$ \\
\hline 9703000000 & The original sculptures and figurines of any material & $\begin{array}{l}\text { Original works of sculptural art of any material [29]; } \\
\text { Original works of art sculpture ... [14] }\end{array}$ \\
\hline 9704000000 & $\begin{array}{l}\text { Postage or revenue stamps, including those of the first } \\
\text { day of maturity, postal stationery articles (stamped } \\
\text { paper), and similar items, used or unused, other than } \\
\text { products of heading } 4907\end{array}$ & $\begin{array}{l}\text { Rare stamps, other philatelic materials, singly or in } \\
\text { collections [14] }\end{array}$ \\
\hline 9705000000 & $\begin{array}{l}\text { Collections and collectibles of zoology, botany, } \\
\text { mineralogy, anatomy or those that are of historical, } \\
\text { archaeological, paleontological, ethnographic or } \\
\text { numismatic interest }\end{array}$ & $\begin{array}{l}\text { Zoological collections representing scientific, cultural, } \\
\text { teaching and educational or aesthetic value; rare } \\
\text { collections and specimens of flora and fauna, } \\
\text { mineralogy, anatomy and paleontology [14] }\end{array}$ \\
\hline 9706000000 & Antiques over 100 years old & $\begin{array}{l}\text { e) antiquities more than } 100 \text { years old, such as } \\
\text { inscriptions, minted coins and stamps; } \\
\text { k) furniture more than } 100 \text { years old and old musical } \\
\text { instruments. [1] Absent in the law [14] }\end{array}$ \\
\hline
\end{tabular}

